\title{
A Daughter's Retrospective of B. F. Skinner
}

\author{
Julie S. Vargas
}

The B. F. Skinner Foundation

This paper describes characteristic behaviors of my father, B. F. Skinner, using family documents and my own recollections. Early contingencies in his upbringing strengthened his love of building things and his independence in discovering how the world works. Those skills, combined with a lack of supervision in graduate school, set the stage for his discovery of the operant. He did not stop with laboratory research. He extended his discovery of how consequences select behavior into education and the design of cultural practices. As well as solving society's problems, my father was always concerned with improving his own behavior. Some of the contingencies he set up to maximize his own productivity are described.

Keywords: Skinner, Biography, Education, Behavior

Este artículo describe algunas de las conductas características de mi padre, B.F. Skinner, usando documentos familiares y mis propios recuerdos. Algunas contingencias tempranas en su crianza fortalecieron su amor por la construcción de objetos y su independencia para descubrir cómo funciona el mundo. Estas habilidades, combinadas con la falta de supervisión en sus años de doctorando, pusieron la base de su descubrimiento del operante. No se limitó al trabajo de laboratorio. Extendió su descubrimiento de cómo las consecuencias seleccionan la conducta a la educación y al diseño de prácticas culturales. Mi padre siempre se preocupó tanto de solucionar los problemas de la sociedad como de mejorar su propia conducta y describo aquí alguna de las contingencias que organizó para maximizar su propia productividad.

Palabras clave: Skinner, Biografía, Educación, Conducta.

Correspondence concerning this article should be addressed to Julie S. Vargas, B.F. Skinner Foundation, 12 Arrow St. \# 303, Cambridge, MA, 02138, United States. E-mail: julie.vargas@bfskinner.org 
My father, B. F. Skinner, was born in Susquehanna a small conservative town nestled in wooded hills of Pennsylvania. His father was a lawyer with a modest practice. His mother was a housewife. He went to the local public schools and graduated second in his class from high school. From these rather modest beginnings, he went on to establish a new science of behavior, different from the S-R psychology of Pavlov and Watson, and different from the "trial and error" analysis of Thorndike. Many people wonder what my father was like as a person and how he became so revolutionary. For not only did he discover the impact of contingencies on behavior, he also extended his analysis to epistemology, education, and cultural design.

Where does behavior come from? Obviously genetics contributes a large part. But the instant a child is born his or her interaction within the immediate setting begins to shape that child's repertoire. Parenting style is a large part of the initial interaction. At one extreme of parenting, a child is given much verbal instruction such as rules about how to behave. At the other end of the continuum a child interacts with nature and others without much adult supervision or guidance. My father's mother, who stayed at home once married, was the main influence in his early life. A clue to her mothering style is found in the "baby book" she kept on my father. One entry says, "Pulled himself up by a chair alone-fourteen months 2 days." Under that is written, "Walked alone July 20th, 1905. Sixteen months old." It took my father two months to take a first step after standing! Clearly his mother did not hurry his walking. Freedom in physical matters seems to have been consistent in his childhood. In his autobiography he mentions roaming the hills without restriction and extreme frustration at trying to turn a screw into an oak plank, not having been told to first drill a hole.

On the other hand, his mother was strict in social matters. Her usual sanction was to say "What will people think?" The two aspects of her child rearing are shown in a story my father reported in his autobiography to solve his forgetting to hang up his pajamas. At breakfast his mother would check. If he had left his pajamas on the bed or floor, he would "have to stop eating, go upstairs, and hang them up." Finally, my father rigged up a gadget to solve his problem. He described the contraption as follows (Skinner, 1976 a, pp.121-122):

The clothes closet in my room was near the door, and in it I fastened a hook on the end of a string which passed over a nail and along the wall to a nail above the center of the door. A sign reading, "Hang up your pajamas" hung at the other end. When the pajamas were in place, the sign was up out of the way, but when I took them off the hook at night, the sign dropped to the middle of the door where I would bump into it on my way out.

I contrast this with my own upbringing: No one made me hang up my pajamas before breakfast, but I'm not sure my mother would have permitted me to drive nails into the door frame and closet area of my bedroom.

By the time he was in elementary school, my father's first love was building things. Among the gadgets he made as a youngster are the following:

- A small reading room with shelves and candle bracket

- Willow whistles, benches, and tables

- Miniature theater with cutout figures, strings and pulleys to open the curtain

- Small houses in backyard and a cabin in the woods

- Slides, teeter-totters, and merry-go-rounds from old lumber

- Scooters from wheels of old roller skates and steerable carts

- Pea shooter, bows and arrows, slingshots

- Steam cannon that would shoot plugs of carrot

- Elaborate hydraulic (water) systems with tubing in grandfather's garage

- Loom that he used to weave mats

- Sprinkler for cleaning floors at the shoe store where he worked

- Gadget to separate ripe elderberries from green ones

- Perpetual motion machine!!! (This one was unsuccessful.)

My father developed an independence both in design and in construction that was to be critical to his discovery years later. I remember him as a Mr. Fix-it. My mother told me that as early as two years old if anything broke, I'd look up at her with a big smile and say, "Daddy fix it". And he would. His gadgets and repairs were not usually very attractive, being made out of old scraps of wood, pieces of metal coat hangers, or other debris kept in the shop of whatever house we were living in, but they worked. Evidence of his "fixes" can still be seen in his last home. An antenna for a small TV is a bent piece of coat hanger. A light switch to enable you to turn off the light at the top of the basement stairs from the bottom consists of a shoehorn attached to nylon fishing line you pull to turn the light off, and a circular ring of metal to pull to turn the light back on. Anyone else would have hired an electrician to put in a downstairs switch. Not my father. Instead he rigged up the nylon lines to operate the upstairs switch from the bottom of the stairs.

In high school my father was not part of any fixed social group. He moved between an Erie Railroad band of mostly older men, a tennis friendship with a Catholic (when his parents were Protestants), friends for exploring, and a teenage dance band he organized. Thus he avoided the strict controls that teenage peers can impose. His independence continued with a canoe trip with four other boys down the Susquehanna River from his home town to Harrisburg, a distance of over 200 kilometers. With another friend he built a cabin in the woods complete with glass windows. His mother's social control followed him even there. "We did not smoke cigarettes," he wrote, "because we were forbidden to do so, but we smoked corn silk and certain kinds of dried leaves" (Skinner, 1976 b. p.123).

In high school he encountered Francis Bacon's works. His teacher, Miss Graves, to whom he later dedicated The 
Technology of Teaching, had her students read Shakespeare's As you Like it. My father's father, probably over the family dinner, had mentioned the theory that Francis Bacon, not Shakespeare, had written that play. My father announced this in class and was roundly admonished. But he did not give up so easily. He went to the library and read everything he could by Bacon. No doubt his new revelations kept that English class interesting, but it is hard to imagine his continued reading just for that discussion. Something in Bacon must have appealed to him. Bacon's insistence that truth was to be found inductively and not through authority would have sounded good to a teenager who loved exploring and tinkering, and who had challenged his teacher. In any case he was to quote "Nature to be commanded must be obeyed" many times in print, and at home.

College furthered his independence in a backhanded way. My father, though very coordinated, had not practiced any sport enough to make a college team. He also did not know about the importance of picking the "right" fraternity and accepted the first request he received, one at the bottom of the social ladder. Thus his first year he did not become part of any one social group. His second year he became an editor of the student publication The Royal Gaboon, and through a tutoring job was invited into the home of the chemistry professor, Percy Saunders, for evenings of chamber music and conversations with well known liberal writers. The Saunders' life appealed to him more than the life he had left back home.

Writing seemed a good career. Encouraged by a letter from Robert Frost, commenting on a story he had sent the poet, my father returned to his parent's home to write the great American novel. He was not successful. Though his parents did not say much, their concern and disapproval must have shown daily in their expressions. Then, too, his new liberal views contrasted with the conservativeness of his parents and their friends. Finally his father gave him a job abstracting legal briefs. That completed, he escaped to New York and got a job in a bookstore. Although he enjoyed the bohemian life, it did not seem a good way to "make something of himself" and he applied to graduate school.

In graduate school at Harvard University, many of my father's strengths came together to enable him to make the discoveries that began a whole new science. As before, he moved between social groups. Although he became friends with the more radical Watsonian students in psychology, his work was guided, at least initially, by William Crozier, the young chair of the new department of physiology. Crozier was a student of Jacques Loeb and expressed acerbic views against the mentalism of Titchener espoused by the chair of psychology, Edwin Boring. After my father's first year of courses, he was essentially on his own to conduct experiments. Here his independence and tinkering skills came into play. Where others might have used standard equipment or followed a professor's agenda, my father worked independently of such constraints. He loved to work alone and to fix things mechanically. He was quick to toss out equipment he had spent hours constructing when he had a better idea of an experimental procedure to try. The result was that the main control over his experimental behavior was the behavior of the organisms he was studying, exactly the right contingencies for discovery. It took over a dozen major pieces of equipment and two and a half years of intense research before he found that the probability of his rats' actions was controlled not by an antecedent stimulus as he had initially thought, but by the immediate postcedent stimulus. This was, indeed, as he wrote to his friend Fred Keller, "a brand new theory of learning" (Keller, 1931).

Finally the small town boy from Pennsylvania had become a success. He was awarded a prestigious fellowship to continue his operant research. He varied every aspect of contingencies he could think of, with gratifying results. When the fellowship was over he found a job at the University of Minnesota. And he found a wife.

That is where I come in. The book about my father's operant research, The Behavior of Organisms, came out in 1938, and I was born the same year. According to my mother, my father, now an expert at behavioral control, discussed child-raising with her. His lifelong fight against punishment of children must have been part of those discussions. My parents had a low coffee table with some attractive knick-knacks on it. At first, like many parents, when I reached for things I was not to touch, my parents gave my hands a little slap. But reaching did not decrease and my father, remembering experiments that showed slaps to only temporarily suppress behavior, suggested never punishing my behavior again. My mother readily agreed. Many years later I heard my father talk about a similar situation. He said something like, "You have a low coffee table with things on it. They are designed to be attractive and they will attract a young child. Instead of punishing the baby's reaching for them, simply put them on a higher shelf, out of reach. The whole idea is to design contingencies to encourage the behavior you want and to eliminate situations that produce behavior you don't want." The knick-knacks in my parents' home were moved from the coffee table to a high shelf.

Although I do not remember the coffee table incident, I do remember allergy testing. I must have been around two years old. In those days the method of testing for allergies was to lay the patient on a table face down and scratch little bits of potent allergens in rows on the patient's bare back. They must have tested a hundred substances on me. I remember squeezing my father's hand and wincing every time a new scratch was made. Needless to say, I did not like going to the hospital. My father mentioned this to the physician who suggested telling me next time that we were going for ice cream. My father was horrified. Instead, for the return trip he told me exactly where we were going. Unwilling to drag me into the hospital, he watched patiently 
as I walked away from the door, around the grass, and finally into the building.

When I was five years old, my mother was pregnant again. She asked my father whether he could make a better crib than the one I had used. As a baby I had worried her when my bed clothes ended up over my head. My father loved to build "equipment" so he happily set to work. The result was the baby tender, an enclosed crib that was heated enough so no sheets or blankets were needed. Pleased with his new invention, my father wrote an article for the Ladies Home Journal. The editor changed his title to "Baby in a Box," thus beginning the confusion between the experimental chamber that everyone but my father called the "Skinner box", and the baby tender. In fact, the new crib was used like other cribs, for sleeping. My sister had a playpen like other babies of the 1940's.

By this time we had moved to Indiana where my father had become chair of the Psychology Department. This was a barren time for research, but he used his administrative position to gather operant researchers together, resulting in the organization from which the Society for the Experimental Analysis of Behavior came. The difference had never been clearer between a mainstream psychology that looked inside the behaving organism for causes, and an operant analysis that looked for causes in the interaction between actions and their surrounding contingencies.

My father loved children, especially his own. He spent much time with my sister and me as we were growing up. Perhaps because of his own frustrations in learning to use tools as a child, he taught my sister and me to use hand tools. We were shown how to drill a hole before putting in a screw. Both Deborah and I had our own hand tools as young children, and my father even built a separate workbench for me in our summer cottage when I was around 13. It had a vise and a set of Craftsman tools mail-ordered from Sears.

In 1947 Edwin Boring, the same professor whose Titchnerian position my father had opposed as a graduate student, invited my father to give the William James Lectures. It seemed to be a way to look over prospective candidates, because at the conclusion of that fall, my father was offered a professorship in the Psychology Department. He accepted and we moved to Cambridge. After two years, my parents built the house they lived in for the rest of their lives. This house was less than a kilometer of my sister's and my elementary school and only two kilometers from my father's office. Every morning we set out together on the few blocks common to our routes. At the end of the day we again had some time with our father. Most evenings, it was our father that put us to bed, reading stories or just talking. Deborah being the younger, was put to bed first. Then he'd come to my bedroom. Both of us developed strategies to keep him talking a little bit longer. Mine was to ask a question about science. The only one that he didn't answer to my satisfaction was "What is beyond space?" As a holding technique this was quite effective, because my father turned on the light, made a mobius strip and had me draw a line, showing how the surface turned back on itself so that, without crossing over an edge, your line covered both sides. "Space," he explained, "is like that, but in three dimensions."

One of my father's favorite activities was taking walks. Our house was near a "garden cemetery" that had wooded hills and ponds. Often my father would take me or Deborah on a walk there. In the other direction, a four kilometer path through woods and meadow circled the Cambridge reservoir. Walks around the reservoir took longer. My father used the longer walks to explain material he was working on for a book or article. Years later, when I read my father's publications, I recognized discussions, like those of the "homunculus" or "operationism" from conversations during those walks.

As much time as our father gave us during the academic year, we had even more of his attention during our summers on Monhegan Island. The island is a small island an hour's boat ride off the coast of Maine. As my father's parents had done, he and my mother gave us complete freedom about where on the island we could go. The only rule was to be back by dinnertime. My sister and I explored the high cliffs on the backside of the island, discovered blackberries on little used trails, and generally went all over the island. The freedom we were given extended to the water. My mother preferred the land to the water, but my father loved to be out on the water. He bought me a Folbot, a rubberized kayac-shaped boat with lee boards and a lateen-rigged sail. It had a tiller that stuck out into the rear sitting space. Always on the lookout for improvements, my father replaced the tiller with a pulley system. Instead of holding your arm out in front of you, you could rest your arm on the side of the boat, moving a cord that ran around the sitting space to move the rudder. My sister had a boat, too. He built her (letting her help, of course) a flat bowed rowboat. Neither of our boats held more than two people, so my father would accompany me sailing, or Deborah rowing and fishing. But often we went out by ourselves.

We kept both boats on Fisherman's Beach, high enough on the beach to escape the high tides of that northern latitude. I could not get my boat down to the water by myself. So my father solved the problem by building a carrier to help. $\mathrm{He}$ made a cradle for the bow that rested on two large wheels. By lifting the stern I could roll the boat down to the water's edge or push it back up to its resting place. Many days I went out sailing accompanied only by my dog or my guitar. Like the stipulations about land, the only rule I had about where I could go was to be back by dinner.

From a World War Two surplus catalog, my father bought a steerable kite with a large picture of a Nazi plane on it designed for target practice off of navy warships. Many days my father and I would launch the kite and steer it back and forth in front of our house. One day my father thought 
the kite might be used to power my sailboat. The problem with a sailboat is that when the wind blows, the boat tips, so that much wind is spilled out of the sail. My father thought, "Why not pull the boat with our steerable kite?" Somewhere he researched this idea and discovered that the ancient Greeks had tried it, but the fact that they had not adopted it did not discourage him. So one day he got the kite up in the air from the beach and set out in the kayak. Fortunately, he had stowed the paddles that came with the boat, because although the kite steered beautifully, the strings curved around in a beautiful arc, so that the kite pulled only in one direction.

There were few organized activities on Monhegan Island. It was up to our family to create things to do. My father was often given things by the fishermen or by the summer artists and he inevitably found something to make of them. One day he came home carrying two enormous pulleys. Soon a "tightrope" appeared. It was only a foot off of the ground, but still offered a challenge. Using old broomsticks for balance and keeping our eyes straight ahead as advised by our father, Deborah and I tried getting across the fourmeter stretch. Neither of us was successful and we soon gave up. The next day, the pulleys appeared in a new role. They supported what we came to call the "trolley". One pulley was attached 3 meters high up a tree at the top of the hill near our house. Another pulley was attached to a tree 20 meters away down over the hill, pulling a rope between the two pulleys taught. Along the rope a third pulley rode with a bar attached. You would start at the top of the hill, hold on to the bar and ride to the bottom, keeping your feet up as high as you could to avoid hitting the ground. This use of the pulleys was successful. We used the "trolley" quite often.

In 1953 my sister was in fourth grade. Visiting her mathematics class one day with other fathers, my father became agitated. Teaching was supposed to be going on, but almost none of what twenty years of research had showed was needed for successful shaping was being used. It was not the teacher's fault. No one person could possibly do what was required for each child. Teachers needed help, and my father had just the solution. As usual, it was a mechanical gadget. That same afternoon he designed the prototype of the first teaching machine. Unlike the worksheets it was designed to replace, it gave feedback following each answer, and it adjusted what the child got next according to performance. Several models of this teaching machine were made and tried out in schools. But it was not until a sabbatical in 1955 that my father tackled the shaping of new skills. He took the sabbatical to finish his book Verbal Behavior. To get away from distractions, he found a little inn near the school in Vermont I attended. He took Deborah with him and she stayed downstairs with the family that ran the inn. While working on his book, he realized that a teaching machine could not only provide practice on skills presumably already taught, but with careful design, material could be presented step by step to shape new skills. He tried out some of his instructional programming with Deborah to great success. Now a new kind of teaching machine would be required. When his sabbatical was over, he designed this new machine and got a small grant to use them to teach his own course. The students' responses were analyzed for revisions and the project was a success. Meanwhile, my father found working with big business terribly frustrating, and he gave up work in education. But the material developed and revised for his undergraduate course is still available on the B. F. Skinner Foundation website, bfskinner.org, and the results of his work can be seen today not only in computer-assistedinstruction, but also in the emphasis on performance objectives, the use of reinforcement instead of punishment, and the increased use of frequent (if not immediate) feedback both to students and to teachers on progress rather than on final performance.

After leaving the field of education, my father turned to society at large. All of the major problems of the timeoverpopulation, the depletion of resources, pollution, and war-involve human actions. In Beyond Freedom and Dignity (Skinner, 1971/2002), my father argued that as a species we have solved physical problems with physical science and that for behavioral problems we need behavioral science. In particular, we need to give up the fiction that our behavior is free, which leads to blaming individuals, and instead to design better the contingencies that actually control what people do. Time Magazine, a prominent weekly, came out with a picture of my father on the cover under the headline "Skinner says we can't afford freedom." Suddenly my father was famous. Or infamous. Many reviewers attacked Beyond Freedom and Dignity with a vehemence that surprised my father, even though he was used to criticism. He pasted the reviews, both good and bad, into a large scrapbook, and tossed it into the back of the basement where it collected spiders along with the boxes of old notes, honorary degrees, and old suitcases. He was now 66 years old.

His new prominence produced many invitations to speak. Too many. As long as I can remember, Deborah and I would encourage our father to turn down talks and consulting invitations, and gradually he turned down more and more. But he rarely turned down requests from former students and never, to my knowledge, an honorary degree. "Resignation" describes how he approached most trips. The commitments he accepted had a way of getting out of hand. He would be invited to give a short talk. Usually he could use something he was working on or planning to write, so that part of the commitment wasn't a problem and he would accept. Then the schedule would come: Since he was going to be on campus, would he visit Professor So and So's class from 9:00 to 10:00? Some students had arranged morning coffee from 10:30 to 11:00. Luncheon would be at the Alumni center with the Dean and a few Department Chairs. 
At 2:00 the local Public Radio would like an interview. At 5:00 cocktails and a dinner with department members was planned, with his talk at 8:00 and a short reception afterwards. That was the official schedule. In addition to that, former students, students working in his field, student reporters, autograph seekers, and various others would call to arrange time to talk. Once accepting a talk my father never learned to say "no" to all the rest. So when an Honorary degree request would come, with the suggestion that perhaps he might "say just a few words" no one in the family was under any illusions about the level of activity expected. Yet when Mother or Deborah or I would say, "Oh yes, just a few words. Oh, and while you're at it, could we have the article? And how about a few informal talks, or a couple of dinners where you could make a few comments...", our father would say, “Oh, you can't turn down an honorary degree!" I don't think my father accepted these invitations with the kind of noblesse oblige that prompted him to accept even inconvenient invitations from former advisees and colleagues. Rather, I think he liked getting honorary degrees. They were proof he had achieved the social status his mother was so concerned about when she asked, "What will people think?"

From his family, my father carried the ethic of leaving the world a better place than you found it and of selfimprovement. As long as I can remember, he worked on his French. He bought the Goncourt journals, but found them too difficult, so he settled on detective stories, and read Simenon's Maigret series in French. Even in his last year, diagnosed with leukemia, he practiced his French pronunciation with the French-speaking secretary that came to the house.

When my father was diagnosed with leukemia, I took a leave of absence to be with him his last few months, and again lived in the house where I grew up. My father continued the early morning schedule I knew so well. He got up before 5:00, got a cup of coffee and went down to his desk. He turned on a light that also controlled a clock. The cumulative records of hours writing each morning show consistent work, even during the early hours of holidays when Deborah's or my family were visiting. If I interrupted his work, he would switch the light off as long as I wanted to talk. When I left, the light, and clock, went back on. At around seven in the morning, he would come up to the main floor, have breakfast while reading the morning paper, and then shower and dress. Then it was time for a walk. Instead of walking the two kilometers to his Harvard Office, his last year he walked around the neighborhood, and of course I would go with him.
From ten until 12:00 he worked with his secretary, answering correspondence, and getting newly typed revisions of manuscripts on which he was working. Unlike his teaching years, he ate lunch at home. After lunch he relaxed with light reading or listening to Wagner, then came up at 5:00 for cocktails with my mother. After dinner, my father watched a bit of TV and then went to bed early, by 9:00 or 10:00. He planned his afternoons and evenings so that he would be in good shape for the next morning's writing.

He was productive to the end. Ten days before he died, he gave a talk to a huge crowd at the annual meeting of the American Psychological Association. My mother and I were there and were impressed with the force of his speech. Still fighting agencyism, he called cognitive psychology the "creationism" of psychology, getting a gasp from most of the audience and a scattering of applause. But at the end he got a standing ovation that lasted the whole time he was helped down the steps and out of the auditorium.

I wish my father were alive to see the ripple effects of his life's work. Operant procedures have created entire fields like behavioral pharmacology. Operant techniques and analysis underpin operant behavior therapy, "Clicker Training", "Tag Teaching,", "Precision Teaching", programmed instruction, and his book Verbal Behavior has been responsible for breakthroughs in the teaching of verbal behavior to children with autism. My father always believed that the best measure of a good science was the technology it spawned. By that measure, his discovery of the selection effect of contingencies qualifies as a very successful science.

\section{References}

Keller, F. S. (1931, October 2) Unpublished letter to B. F. Skinner. Harvard University Archives, Cambridge, MA.

Skinner, B. F. (1938/1991). The behavior of organisms. Cambridge, MA: B. F. Skinner Foundation.

Skinner, B. F. (1957/1992). Verbal behavior. Cambridge, MA: B. F. Skinner Foundation.

Skinner, B. F. (1968/2003). The technology of teaching. Cambridge, MA: B. F. Skinner Foundation.

Skinner, B. F. (1976). Particulars of my life. New York: Knopf.

Skinner, B. F. (1971/2002). Beyond freedom and dignity. MA: Hackett Publishing.

Received September, 1, 2004

Accepted September, 15, 2004 